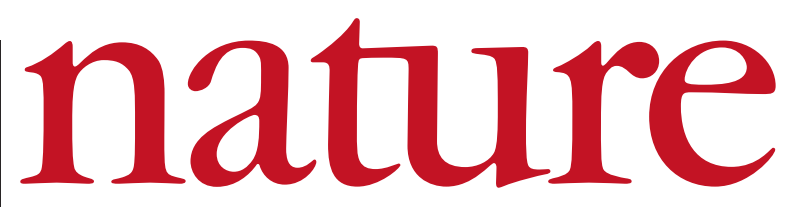

2 May 2002 Volume 417 Issue no 6884

\title{
Don't boycott Israel's scientists
}

A petition urging European institutions to initiate moratoria against scientific collaboration with Israel has sparked further petitions and counter-petitions. Such boycotts are misguided and should be opposed in favour of constructive initiatives.

S cience is less political than other issues, and is a bridge for peace. That is what Leah Boehm, then chief scientist at Israel's science ministry, enthusiastically told Nature in 1995. Then, Israeli and Palestinian researchers were optimistic that the peace process would cause funds to flow to joint Arab-Israeli projects from the international community, reinforcing peace by contributing to dialogue, and boosting research in the region to better manage water and other scarce local resources, protect the environment and fight disease.

Subsequent events have left these noble aspirations in tatters. If the world's scientific community can do anything to encourage Middle-East peace they should jump at it. Unfortunately, initiatives taken by some academics are running counter to these aims. Steven and Hilary Rose, from Britain's Open University, instigated a petition in a UK newspaper, The Guardian, calling for a European boycott of research and cultural links with Israel until the latter "abides by UN resolutions and opens serious peace negotiations with the Palestinians". Some 300 academics have already signed this petition, while broader boycott initiatives have since sprung up in France and several other countries.

Ariel Sharon has already defied the United Nations and most of the international community; it is naive to think he is going to lose a moment's sleep over his country's researchers being turned into pariahs. More importantly, as is summed up well in many of the responses and counter-petitions that have been launched (see, for example, http://euroisrael.huji.ac.il/news.html and the Correspondence on page 15 of this issue), the concept of a research boycott restricts channels that are better kept open. Ironically, the majority of Israeli scientists are on the political left and support the peace process. Why should they be punished for the excesses of their political leaders?

The boycott is also partisan. Scientists have as much right to express their diverse views on the Israeli-Palestinian conflict as other citizens, but the 'logic' of politically motivated boycotts is too readily extensible to the point of absurdity - should we also boycott Palestinian researchers because the Palestinian Authority has not done enough to prevent suicide bombers?

Many Israeli scientists are open to collaboration with Palestinian and other Arab scientists. Take the joint graduate programme between Tel Aviv University and Bethlehem University involving geneticist Mary-Claire King at the University of Washington. This project is looking at the genetic origins of deafness, and the Middle East is ideal for such research, as rich pedigrees are available because marrying close relatives is unusually common. Moreover, Bethlehem researchers have spent time in King's laboratory, bringing back new skills to Palestine. King, who knows the realities on the ground, opposes the boycott, arguing that the three-way collaboration is an example of a successful effort to maintain such constructive contact.

This is just one example of partnerships involving Israel, its neighbours and scientists in Europe or the United States. Israel is a research powerhouse that, given an eventual improvement of relations with its neighbours, could rejuvenate science and development in the region through collaboration and training. Rather than signing boycotts, which will achieve nothing, researchers worldwide can help the peace process concretely by actively initiating more of such three-way collaborations - and encouraging their institutions to do the same.

\section{Selling science to the young}

\section{More needs to be done to tell people about the rewards of careers outside science as well as inside it.}

$\mathrm{T}$ here is a problem with the younger generation. Across the world, young people in schools are choosing not to experiment with dangerous chemicals, many are failing to gaze into space, and some are even losing interest in sexual reproduction. Clearly something has to be done.

Falling interest in science - the physical sciences in particular among teenagers is of global concern. Recent reports have highlighted a collapse in the number of students choosing to study chemistry and physics at university: UK chemistry students are down by $25 \%$ and physics students in France have fallen by $46 \%$ over recent years. Germany, the United States and Japan face similar problems.

Some of the reasons for this are well rehearsed. Science is universally acknowledged to be a relatively difficult subject, and at school level it is crammed with facts, leaving little room for creativity or debate. Some are already trying to strip down science curricula to address this.

Other reasons for the malaise given in individual countries range from the decline in experimental work in science lessons to the decision to bundle chemistry, physics and biology together to be taught as 'science', as well as low pay and poor-quality teaching.

The proposed solutions are equally familiar and often revolve around better 'engaging' young people with science. Typical schemes see postgraduate students visit local schools and participate in science lessons. These are noble attempts, but the lure of a career and ready cash should not be underestimated — increasing numbers of students choose their degrees, and hence their school subjects, with these in mind. How many students chose to become well-paid accountants because they were 'engaged' with that subject?

Nature would be the first to point out that few researchers working in cash-strapped universities are in it for the money. Nevertheless, many graduates do turn their science degrees into decent financial as well as spiritual reward. Are students aware of this? A recent review of the supply of scientists and engineers in Britain suggested not, pointing out that few pupils make a link between what they view as vocational scientific subjects and the possibility of alternative future careers.

This perception needs to be reversed. Scientific societies should do more to highlight those who have used a scientific training as a springboard to lucrative careers outside their discipline. Those giving careers advice in schools must ensure that students see the well-paid opportunities for those with science backgrounds, not just in research but in finance, business - even, dare we say it, the media. 